\title{
Diversity of ants and mites in the diet of the Brazilian frog Chiasmocleis leucosticta (Anura: Microhylidae)
}

\author{
Mariana S. Lopes ${ }^{I}$, Ricardo S. Bovendorp ${ }^{I}$, Gilberto José de Moraes ${ }^{I}$, Alexandre Reis Percequillo ${ }^{I} \&$ \\ Jaime Bertoluci ${ }^{1 *}$ \\ ${ }^{1}$ Universidade de São Paulo, Escola Superior de Agricultura Luiz de Queiroz, Piracicaba, Brazil \\ *Corresponding Author: Dr. Jaime Bertoluci, e-mail: jaime.bertoluci@usp.br
}

\begin{abstract}
LOPES, M. S., BOVENDORP, R. S., DE MORAES, G. J., PERCEQUILLO, A. R., BERTOLUCI, J. Diversity of ants and mites in the diet of the Brazilian frog Chiasmocleis leucosticta (Anura: Microhylidae). Biota Neotropica. 17(3): e20170323. http://dx.doi.org/10.1590/1676-0611-BN-2017-0323
\end{abstract}

\begin{abstract}
We describe here the diet of the microhylid frog Chiasmocleis leucosticta based on the stomach contents of 72 individuals (47 males and 25 females) collected in pitfall traps at the Reserva Florestal de Morro Grande, state of São Paulo, southeastern Brazil. We identified 1,981 food items distributed in 13 prey categories of arthropods, mainly ants, mites and collembolans. Formicidae was the most abundant and frequent prey category, including 16 genera from seven subfamilies, and data on ant availability in the habitat suggest that C. leucosticta selects ants actively. The second main prey category was Acari, predominantly represented by mites of the suborder Oribatida. This is the first work identifying mites to the family level in the diet of a Microhylidae. There was no statistical difference between males and females regarding diet composition.
\end{abstract}

Keywords: Acari, Anuran, Atlantic Rainforest, Food habits, Formicidae, Myrmecophagy.

\section{Diversidade de formigas e ácaros na dieta do anuro brasileiro Chiasmocleis leucosticta (Anura: Microhylidae)}

\begin{abstract}
Resumo: Descrevemos neste trabalho a dieta do anuro Chiasmocleis leucosticta, pertencente à família Microhylidae, com base no conteúdo estomacal de 72 indivíduos (47 machos e 25 fêmeas) coletados em armadilhas-de-queda na Reserva Florestal de Morro Grande, SP. Foram identificados 1981 itens alimentares, distribuídos em 13 categorias de artrópodes, especialmente formigas, ácaros e colêmbolos. Formicidae foi a categoria de presas mais abundante e frequente, incluindo 16 gêneros pertencentes a sete subfamílias. Os dados de disponibilidade de formigas no ambiente sugerem que C. leucosticta seleciona formigas ativamente. A segunda categoria de presas mais relevante foi Acari, predominantemente representada por ácaros da subordem Oribatida. Este é o primeiro trabalho que identifica os ácaros ao nível de família na dieta de um Microhylidae. Não houve diferença estatística entre machos e fêmeas quanto à composição da dieta.
\end{abstract}

Palavras-chave: Acari, Anuros, Mata Atlântica, Hábitos alimentares, Formicidae, Mirmecofagia.

\section{Introduction}

The anuran family Microhylidae is composed of 13 subfamilies and 612 species (Frost 2017), comprising about 8\% of the global anuran diversity (Sá et al. 2012), and distributed worldwide, except in Europe (Vitt \& Caldwell 2013, Pough et al. 2016). Microhylids are extremely diversified in habits, and fossorial and semifossorial species tend to be myrmecophagous, feeding on ants and termites (Vitt \& Caldwell 2013). The gastrophrynine genus Chiasmocleis (Méhelÿ, 1904) is widely distributed and the most speciose genus among tropical microhylids (Van Sluys et al. 2006, Forlani, 2010). Currently, the genus comprises 29 species, which are spread from Panama to Southern Brazil (Frost 2017), including 11 species found in the Atlantic rainforest of southeastern Brazil.

Information about the food habits of Chiasmocleis species is scarce, ants being the most common item of the diet (Duellman 1978, Schlüter \& Salas 1991; Caramaschi \& Cruz 2001, Van Sluys et al. 2006).
Chiasmocleis leucosticta (Boulenger, 1888) is found in Brazilian Atlantic rainforest areas from São Paulo to Santa Catarina states (Cruz et al. 1997). Similarly to the other species of the genus, C. leucosticta is fossorial and an explosive breeder, characterized by large aggregations in temporary water bodies during a very short period of the year (Van Sluys et al. 2006). Thereby, due to their fossorial habits and annual breeding pattern, individuals are rarely found, and natural history data about the species are rare.

We describe here the diet of Chiasmocleis leucosticta based on stomach contents and test if there are dietary differences between the sexes.

\section{Material and Methods}

This study was conducted with individuals of $C$. leucosticta collected accidentally in pitfalls traps used to sample arthropods in a study on rodent ecology (Bovendorp 2013) in the Reserva Florestal de Morro Grande, Cotia municipality, state of São Paulo, southeastern 
Brazil $\left(23^{\circ} 39^{\prime}-23^{\circ} 48^{\prime} \mathrm{S}, 46^{\circ} 55^{\prime}-47^{\circ} 01^{\prime} \mathrm{W}\right)$. Climate in this area is Cfb of Koeppen, warm temperate and humid, and mean annual rainfall is $1339 \mathrm{~mm}$ (Metzger et al. 2006). The reserve locates in a continuum of montane rainforest, between the Atlantic and the Semideciduous forests (Aragaki \& Mantovani 1998, Catharino et al. 2006), occupying an area of 9,400 ha; vegetation is composed by a mosaic of secondary forests in different stages of conservation and mature forests (Metzger et al. 2006).

Sampling occurred monthly (five days) between January 2008 and January 2010. Two additional samples were performed in July 2010 (16 days) and January 2011 (13 days). Traps (400 mL plastic cups) were buried at soil level and filled with $200 \mathrm{~mL} 92 \%$ alcohol in three areas with different successional stages in a grid consisting of six lines with $100 \mathrm{~m}$ separated by $20 \mathrm{~m}$ (six equidistant traps in each line), totalling 36 traps per area.

All frogs had their snout-vent length (SVL) measured with digital callipers to the nearest $0.5 \mathrm{~mm}$. Animals were dissected, and food items were determined to the lowest possible taxonomic level under stereo microscopes (Motic K-700L and Zeiss Discovery V20) with the aid of dichotomy keys (Rafael et al. 2012, for insect orders, Fernández 2003, for subfamilies and genera of Formicidae). Mites were mounted in Hoyer's medium on microscope slides and identified to family using keys provided in Krantz $\&$ Walter (2009). Total number of each prey category was counted, and frequency of occurrence was calculated by the ratio between the number of stomachs with the prey category and the total number of stomachs (empty stomachs were excluded).

All results were compared between males and females with t-student test (Zar 1999). The sexes were determinate by the presence or the absence of ovaries and oviducts. Voucher material (frogs and stomach contents) was deposited in the herpetological collection of the Laboratório de Zoologia de Vertebrados, Escola Superior de Agricultura Luiz de Queiroz, Universidade de São Paulo (acronym VESALQ), but mites were deposited in the mite reference collection of the Departamento de Entomologia e Acarologia of the same institution.

\section{Results}

We analyzed 72 individuals of C. leucosticta (47 males and 25 females). Only one stomach was empty, which was excluded from the analysis. We identified 1,981 food items distributed in 13 prey categories (Table 1). The diet was composed solely of arthropods, mainly ants, mites and collembolans. Formicidae was the more abundant and frequent prey category. Furthermore, we found a high diversity of ants in the diet (16 genera from seven subfamilies), Myrmicinae being the most abundant and frequent ant subfamily, mostly represented by the genera Pheidole and Solenopsis (Table 2).

The second main prey category was Acari, predominantly represented by the suborder Oribatida, with 33 individuals (Table 3). Other prey categories appeared in low abundances (one to five individuals). Crustaceans and hemipterans were identified only in males, while non-ant hymenopterans and carabid larva were found only in females. The presence of plant material in the stomachs was interpreted as accidental ingestion.

There was no statistical difference between males and females regarding diet composition $(\mathrm{t}=0.5022, \mathrm{p}>0.05)$.

\section{Discussion}

In this study, only one stomach (1.4\%) was empty. The proportion of empty stomachs is highly variable in Chiasmocleis species whose diet was determined, varying from $19.3 \%$ in C. capixaba (Van Sluys et al. 2006) to $82.3 \%$ in C. ventrimaculata (Schluter \& Salas 1991).

Our results suggest that Chiasmocleis leucosticta is an ant and mite specialist anuran (sensu Toft 1981), as many other Neotropical [C. antipes, C. bassleri (Duellman 1978), C. ventrimaculata (Schluter \& Salas 1991), C. capixaba (Van Sluys et al. 2006), C. albopunctata (Araújo et al. 2009), Hamptophryne boliviana (Schluter \& Salas 1991), Elachistocleis ovalis (Solé et al. 2002), and E. bicolor (Berazategui et al. 2007, Araujo et al. 2009)], and Australian [e.g., Cophyxalus spp. (Williams et al. 2006, Hoskin \& Aland 2011] microhylids. Data on arthropod availability at Reserva

Table 1. Food items of the diet of the microhylid frog Chiasmocleis leucosticta. $\mathrm{N}=$ total number of prey by category; $\mathrm{F}=$ frequency of prey categories.

\begin{tabular}{|c|c|c|c|c|c|}
\hline \multirow{2}{*}{ Prey categories } & & \multicolumn{2}{|c|}{ Males $(n=47)$} & \multicolumn{2}{|c|}{ Females $(n=24)$} \\
\hline & & $\mathbf{N}$ & $\mathbf{F}$ & $\mathbf{N}$ & $\mathbf{F}$ \\
\hline \multicolumn{6}{|l|}{ ARACHNIDA } \\
\hline Acari & & 34 & 0.447 & 18 & 0.542 \\
\hline Araneae & & 7 & 0.149 & 2 & 0.083 \\
\hline CRUSTACEA & & 3 & 0.064 & - & - \\
\hline \multicolumn{6}{|l|}{ HEXAPODA } \\
\hline Collembola & & 16 & 0.191 & 8 & 0.208 \\
\hline Diptera & & 1 & 0.021 & 2 & 0.083 \\
\hline \multicolumn{6}{|l|}{ Hemiptera } \\
\hline & Heteroptera & 2 & 0.043 & - & - \\
\hline & Sternorryncha & 8 & 0.149 & 2 & 0.083 \\
\hline \multicolumn{6}{|l|}{ Hymenoptera } \\
\hline & Formicidae & 498 & 0.830 & 328 & 0.917 \\
\hline & Remains of Formicidae (number of ant heads) & 740 & 0.894 & 272 & 0.833 \\
\hline & Other (no-ant) & - & - & 4 & 0.167 \\
\hline \multicolumn{6}{|l|}{ Insect larvae } \\
\hline & Carabeidae & - & - & 1 & 0.042 \\
\hline & Diptera & 6 & 0.064 & 2 & 0.042 \\
\hline & undetermined & 1 & 0.021 & 1 & 0.042 \\
\hline PLANT MATERIAL & & & 0.213 & & 0.250 \\
\hline UNIDENTIFIED & & & 18 & 0.255 & 7 \\
\hline Total & & 1334 & & 647 & \\
\hline
\end{tabular}


Myrmecophagy in Chiasmocleis leucosticta

Table 2. Subfamilies and genera of Formicidae found in the diet of the microhylid frog Chiasmocleis leucosticta. $\mathrm{N}=$ total number of ants; $\mathrm{F}=$ frequency of ants.

\begin{tabular}{|c|c|c|c|c|c|}
\hline \multirow{2}{*}{ Subfamilies } & \multirow{2}{*}{ Genera } & \multicolumn{2}{|c|}{ Males $(n=47)$} & \multicolumn{2}{|c|}{ Females $(n=24)$} \\
\hline & & $\mathbf{N}$ & $\mathbf{F}$ & $\mathbf{N}$ & $\mathbf{F}$ \\
\hline \multirow[t]{3}{*}{ Cerapachyinae } & & 6 & 0.064 & 1 & 0.042 \\
\hline & Acanthostichus & 4 & 0.043 & 1 & 0.042 \\
\hline & Undetermined & 2 & 0.021 & - & - \\
\hline \multirow[t]{2}{*}{ Ecitoninae } & & 3 & 0.043 & 75 & 0.167 \\
\hline & Labidus & 3 & 0.043 & 75 & 0.167 \\
\hline \multirow[t]{2}{*}{ Ectatomminae } & & 50 & 0.340 & 40 & 0.333 \\
\hline & Gnamptogenys & 50 & 0.340 & 40 & 0.333 \\
\hline \multirow[t]{4}{*}{ Formicinae } & & 43 & 0.085 & 47 & 0.250 \\
\hline & Brachemyrmex & - & - & 17 & 0.021 \\
\hline & Paratrechina & 9 & 0.043 & 2 & 0.042 \\
\hline & Undetermined & 34 & 0.043 & 28 & 0.167 \\
\hline \multirow[t]{2}{*}{ Heteroponerinae } & & 4 & 0.064 & 3 & 0.125 \\
\hline & Heteroponera & 4 & 0.064 & 3 & 0.125 \\
\hline \multirow[t]{11}{*}{ Myrmicinae } & & 372 & 0.596 & 139 & 0.667 \\
\hline & Acanthognatus & - & - & 1 & 0.042 \\
\hline & Adelomyrmex & 1 & 0.021 & - & - \\
\hline & Basiceros & 2 & 0.043 & - & - \\
\hline & Crematogaster & - & - & 10 & 0.042 \\
\hline & Cyphomyrmex & 5 & 0.042 & - & - \\
\hline & Pheidole & 306 & 0.383 & 86 & 0.500 \\
\hline & Solenopsis & 40 & 0.234 & 40 & 0.250 \\
\hline & Strumigenys & 4 & 0.064 & - & - \\
\hline & Wasmania & 5 & 0.021 & - & - \\
\hline & Undetermined & 9 & 0.128 & 2 & 0.042 \\
\hline \multirow[t]{4}{*}{ Ponerinae } & & 18 & 0.213 & 15 & 0,167 \\
\hline & Odontomachus & 1 & 0.021 & 3 & 0.042 \\
\hline & Hypoponera & 16 & 0.191 & 12 & 0.125 \\
\hline & Undetermined & 1 & 0.021 & - & - \\
\hline Unidentified & & 1 & 0.021 & 1 & 0.042 \\
\hline
\end{tabular}

Table 3. Mites found in the diet of the microhylid frog Chiasmocleis leucosticta. $\mathrm{N}=$ total number of mites; $\mathrm{F}=$ frequency of mites.

\begin{tabular}{lcccccc}
\hline & \multicolumn{2}{c}{ Males $(\mathbf{n}=\mathbf{4 7})$} & & \multicolumn{2}{c}{ Females $(\mathbf{n}=\mathbf{2 4})$} \\
\cline { 2 - 3 } \cline { 5 - 6 } & $\mathbf{N}$ & $\mathbf{F}$ & & $\mathbf{N}$ & $\mathbf{F}$ \\
\hline Mesostigmata & $\mathbf{4}$ & $\mathbf{0 . 0 6 4}$ & & 7 & $\mathbf{0 . 2 5 0}$ \\
Laelapidae & - & - & & 2 & 0.042 \\
Macrochelidae & - & - & & 2 & 0.083 \\
Podocinidae & 4 & 0.064 & & 1 & 0.042 \\
Rhodacaridae & - & - & & 1 & 0.042 \\
Veigaiidae & - & - & & 1 & 0.042 \\
Oribatida & 25 & $\mathbf{0 . 2 9 8}$ & & $\mathbf{8}$ & $\mathbf{0 . 2 5 0}$ \\
Prostigmata & - & - & & $\mathbf{1}$ & $\mathbf{0 . 0 4 2}$ \\
Smarididae & - & - & & 1 & 0.042 \\
Unidentified & $\mathbf{5}$ & $\mathbf{0 . 1 0 6}$ & & $\mathbf{2}$ & $\mathbf{0 . 0 8 3}$ \\
\hline
\end{tabular}

Florestal do Morro Grande indicate that Formicidae was not the most abundant item along the year neither in number of individuals nor in biomass (Bovendorp 2013), which suggests that the prevalence of ants in the diet of C. leucosticta in this study is related to prey selection by C. leucosticta.

Myrmicinae ants dominated the diet of $C$. leucosticta, which can be explained by the higher diversity of genera and habits (arboreal, soil and leaf litter inhabitants, and some associated with plants, fungus and other ants) of this taxon when compared with other ant subfamilies (Fernández 2003). All Myrmicinae genera found in our study include leaf litter or epigean ants, except Crematogaster, an arboreal genus that can be associated with plants and other ants (Fernández 2003). Crematogaster ants were found only in one stomach, suggesting the predation event occurred when those were foraging in the leaf litter. Among Myrmicinae, Pheidole was the most speciose genus, followed by Solenopsis; Pheidole is the most common genus in the Neotropics and very abundant locally, comprising up to 70 species by locality, while Solenopsis includes about 90 species (Fernández 2003). These two genera were also the most abundant in the diet of the microhylid Elachistocleis ovalis (Solé et al. 2002).

Considering males and females together, Formicinae and Ectatomminae were the second most abundant food category in our study. Formicinae ants are characterized by the production of formic acid and by the presence of venom gland; Brachemyrmix is a common genus in the soil and leaf litter, and Paratrechina is a cosmopolitan genus in natural and disturbed habitats (Fernández 2003). Solé et al. (2002) found that although the genus Paratrechina is present in the diet of E. ovalis, in field experiments the frogs adopted defensive postures when these ants were offered to them as potential prey. The relatively high consumption of Formicinae in this study (10 frogs) indicates that this behavior may not be present in C. leucosticta.

The only Ectatomminae ants our frogs ingested belong to the genus Gnamptogenys, represented in the Neotropics by 81 species of predatory ants inhabiting the forest floor or the vegetation (Fernández 2003). Ecitoninae ants are the famous legionary ants, nomad predators that live in dense colonies, alternating stationary and migratory stages; ants in the genus Labidus impose heavy impact on invertebrate populations (Fernández 2003). Six out the nine ant genera consumed by the microhylid Elachistocleis ovalis (Solé et al. 2002) were also consumed by C. leucosticta (Cyphomyrmex, Pheidole, Solenopsis, Wasmannia, Gnamptogenys, and Hypoponera). 
Mites have been rarely reported as food items to anurans. Duellman (1978) did not find mites in the diet of Chiasmocleis anatipes, C. bassleri and C. ventrimaculata, while Schluter \& Salas (1991) reported two individuals C. ventrimaculata feeding on mites at night (but did not find them in the stomachs). The importance of mites in the diet of $C$. leucosticta may be explained by the fact that this group of organisms is the most abundant in the forest floor, especially the Oribatida (Franklin et al. 2001), which suggests that its presence could be due to the great abundance rather than a food preference. Mites of this group are mostly known for being mainly saprophagous and/or fungivorous, thus being more numerous in soil covered with abundant litter (Norton \& Behan-Pelletier 2009). All other mite families found in this study are known mainly for their predatory habits, being typically soil inhabitants (Carrillo et al. 2015).

Some Chiasmocleis species are considered important mite predators in leaf litter communities, the level of acarophagy being negatively correlated to the anuran body size (Simon and Toft 1991). Chiasmocleis leucosticta is a small (male $\mathrm{SVL}=18.3 \pm 2.80 \mathrm{~mm}$; female $\mathrm{SVL}=23.5 \pm 1.72 \mathrm{~mm}$ ) fossorial frog that forages in the leaf litter, being included in Class 2 of Simon \& Toft (1991), which could explain the presence and the relative abundance of mites in its diet. Mites were also well represented in the diet of the Amazonian microhilyd Sincope antenori (Simon \& Toft 1991) and in the Atlantic forest microhylid Chiasmocleis capixaba (Van Sluys et al 2006). To our knowledge this is the first work to identify mites to the family level in the diet of a Microhylidae frog.

Some dendrobatid frogs are able to remove alkaloids from their diets (especially from ants, bees, millipedes and mites) and turn them into chemical defenses (Saporito et al. 2004). Myrmicinae ants have several alkaloids, such as pyrrolidine, pyrrolizidine, piperidine, indolizidine, and quinolizidine decahydroquinoline (Daly et al. 1994a, 2000). Similarly, pumiliotoxins were also found in Brachemyrmix and Paratrechina ants (Saporito et al. 2004). Since most microhylids are ant-specialists, some studies have investigated whether microhylids are able to remove alkaloids from the diet. Berazategui et al. (2007) pointed out that the high consumption of Myrmicinae suggests that Elachistocleis bicolor is able to capture alkaloids. However, as toxicity is generally associated to diurnal activity and aposematism, the adaptive nature of this character in E. bicolor, a cryptic and nocturnal species, remains unclear. Additionally, Mebs et al. (2010) were unable to detect alkaloids in the skin of Elachistocleis sp. from Bolivia, but have detected them in the dendrobatid Ameerega picta, concluding that "myrmecophagy provides dendrobatids with alkaloids, which they sequester and store in their skin, but an alkaloid sequestering system is absent in the microhylid Elachistocleis sp." This system of alkaloid sequestration was previously described for dendrobatids by Daly et al. (1994b), and it is probably absent in ant-specialized microhylids.

Some studies have been conducted to verify the presence of alkaloids in mites. Saporito et al. (2007) isolated more than 80 alkaloids from oribatid mites, and half of them are also present in the dendrobatid Oophaga pumilio. Oribatid mites are the main source of alkaloids to Dendrobatidae and Eleutherodactylidae (Raspotnig et al. 2011). For the same reason discussed above for ants, microhylids seem to be unable to sequester alkaloids from their mite prey.

\section{Author Contributions}

Mariana S. Lopes: conceptualization, methodology, laboratory work (dissections, ant determination), data analysis, validation, writing.

Ricardo S. Bovendorp: methodology, fieldwork (anuran collection), funding acquisition, validation, writing.

Gilberto José de Moraes: methodology, laboratory work (mite determination), resources, validation, writing.

Alexandre Reis Percequillo: methodology, funding acquisition, resources, project administration, supervision, validation, writing.
Jaime Bertoluci: conceptualization, methodology, funding acquisition, resources, project administration, supervision, validation, writing.

\section{Conflicts of interest}

The authors have declared that no conflicts of interest exist.

\section{References}

ARAGAKI, S. \& MANTOVANI, W. 1998. Caracterização do clima e da vegetação de remanescente florestal no planalto paulista (SP). Publicações ACIESP 104:25-36.

ARAÚJO, M.S., BOLNICK, D.I., MARTINELLI, L.A., GIARETTA, A.A. \& REIS, S.F. 2009. Individual-level diet variation in four species of Brazilian frogs. J. Anim. Ecol. 78:848-856.

BERAZATEGUI, M., CAMARGO, A. \& MANEYRO, R. 2007. Environmental and seasonal variation in the diet of Elachistocleis bicolor (Guérin-Méneville 1838) (Anura: Microhylidae) from Northern Uruguay. Zool. Sci. 24:225-231.

BOVENDORP, R.S. 2013. História natural e ecologia de duas espécies de roedores simpátricas da tribo Oryzomyini (Cricetidae: Sigmodontinae) Floresta Atlântica [doctoral thesis]. Piracicaba: Escola Superior de Agricultura Luiz de Queiroz, Universidade de São Paulo.

CARAMASCHI, U. \& CRUZ, C.A.G. 2001. A new species of Chiasmocleis Méhelÿ, 1904 from Brazilian Amazonia (Amphibia, Anura, Microhylidae). Bol Mus Nac Rio de Janeiro, N.S. Zoologia 469:1-8

CARRILLO, D., MORAES, G.J. \& PEÑA, J. 2015. Prospects for biological control of plant feeding mites and other harmful organisms. Cham: Springer. 328p.

CATHARINO, E.L.M., BERNACCI, L.C., FRANCO, G.A.D.C., DURIGAN, G. \& METZGER, J.P. 2006. Aspectos da composição e diversidade do componente arbóreo das florestas da Reserva Florestal do Morro Grande, Cotia, SP. Biota Neotropica 6:1-28.

CRUZ, C.A.G., CARAMASCHI, U. \& IZECKSOHN, E. 1997. The genus Chiasmocleis Mehely, 1904 (Anura, Microhylidae) in the Atlantic Forest of Brazil, with description of three new species. Alytes 15:49-71.

DALY, J.W., GARRAFFO, H.M., SPANDE, T.F., JARAMILLO, C. \& RAND, A.S 1994A. Dietary source of skin alkaloids of poison frogs (Dendrobatidae)? J. Chem. Ecol. 20:943-955.

DALY, J.W., SECUNDA, S.I., GARRAFFO, H.M., SPANDE, T.F., WISNIESKI, A. \& COVER, J.F. 1994B. An uptake system for dietary alkaloids in poison frogs (Dendrobatidae). Toxicon 32:657-663.

DALY, J.W., GARRAFFO, H.M., JAIN, P., SPANDE, T.F., SNELLING, R.R., JARAMILLO, C. \& RAND, A.S. 2000. Arthropod-frog connection: decahydroquinoline and pyrrolizidine alkaloids common to microsympatric myrmicine ants and dendrobatid frogs. J. Chem. Ecol. 26:73-85.

DUELLMAN, W.E. 1978. The Biology of an Equatorial Herpetofauna in Amazonian Ecuador. Misc. Publ. Mus. Nat. Hist. Univ. Kansas 65:1-352.

FERNÁNDEZ, F. (Ed.). 2003. Introducción a las hormigas de la región Neotropical. Bogotá: Instituto de Investigación de Recursos Biológicos Alexander von Humboldt. 398 p.

FORLANI, M.C. 2010. Variação morfológica do gênero Chiasmocleis Méhely 1904 (Anura, Microhylidae, Gastrophryninae) e suas implicações filogenéticas. [MSc dissertation]. São Paulo: Universidade de São Paulo.

FRANKLIN, E.N., MORAIS, J.W. \& SANTOS, E.M.R. 2001. Density and biomass of Acari and Collembola in primary forest, secondary forest and polycultures in central Amazônia. Andrias 15:141-153.

FROST, D.R. 2017. Amphibian Species of the World: an Online Reference. Version 6.0 (accessed 2 March 2017). Electronic database accessible at http://research amnh.org/herpetology/amphibia/index.html. American Museum of Natural History, New York, USA.

HOSKIN, C.J. \& ALAND, K. 2011. Two new frog species (Microhylidae: Cophixalus) from boulder habitats on Cape York Peninsula, north-east Australia. Zootaxa 3027:39-51

MEBS, D., JANSEN, M., KOHLER, G., POGODA, W. \& KAUERT, G. 2010. Myrmecophagy and alkaloid sequestration in amphibians: a study on Ameerega picta (Dendrobatidae) and Elachistocleis sp. (Microhylidae) frogs. Salamandra 46:11-15. 
METZGER, J.P., ALVES, L.F., GOULART, W., TEIXEIRA, A.M.G., SIMÕES, S.J.C. \& CATHARINO, E.L.M. 2006. Uma área de relevante interesse biológico, porém pouco conhecida: a Reserva Florestal do Morro Grande. Biota Neotropica 6:1-33.

POUGH, F.H., ANDREWS, R.M., CRUMP, M.L., SAVITZKY, A.H., WELLS, K.D. \& BRANDLEY, M.C. 2016. Herpetology. 4th ed. Sinauer Associates. 718 pp.

RAFAEL, J.A., MELO, G.A.R., CARVALHO, C.J.B, CASARI, S.A. \& CONSTANTINO, R. (Eds.). 2012. Insetos do Brasil: Diversidade e Taxonomia. Ribeirão Preto: Holos Editora. 810p.

RASPOTNIG, G., NORTON, R.A. \& HEETHOFF, M. 2011. Oribatid mites and skin alkaloids in poison frogs. Biol. Lett. 7:555-556.

SÁ, R.O., STREICHER, J.W., SEKONYELA, R., FORLANI, M.C., LOADER, S.P., GREENBAUM, E., RICHARD, S. \& HADDAD, C.F.B. 2012. Molecular phylogeny of microhylid frogs (Anura: Microhylidae) with emphasis on relationships among New World genera. BMC Evol. Biol. 12:241-262.

SAPORITO, R.A., DONNELLY, M.A., NORTON, R.A., GARRAFFO, H.M., SPANDE, T.F. \& DALY, J.W. 2007. Oribatid mites as a major source for alkaloids in poison frogs. Proc. Nat. Acad. Sci. USA 104:8885-8890.

SAPORITO, R.A., GARRAFFO, H.M., DONNELLY, M.A., EDWARDS, A.L., LONGINO, J.T. \& DALY, J.W. 2004. Formicine ants: an arthropod source for the pumiliotoxin alkaloids of dendrobatid poison frogs. Proc. Nat. Acad. Sci. USA 104:8045-8050.

SCHLÜTER, A. \& SALAS, A.W. 1991. Reproduction, tadpoles and ecological aspects of three syntopic microhylid species from Peru (Amphibia: Microhylidae). Stutt. Beitr. Naturkd. 458:1-17.
SIMON, M.P. \& TOFT, C.A. 1991. Diet specialization in small vertebrates: miteeating in frogs. Oikos 61:263-278.

SOLÉ, M., KETTERL, J., DI BERNARDO, M. \& KWET, A. 2002. Ants and termites are the diet of the microhylid frog Elachistocleis ovalis (Schneider, 1799) at an Araucaria forest in Rio Grande do Sul, Brazil. Herp. Bull. 79:14-17.

TOFT, C.A. 1981. Feeding ecology of Panamanian litter anurans: patterns in diet and foraging mode. J. Herpetol. 15:139-144.

VAN SLUYS, M., SCHITTINI, G.M., MARRA, R.V., AZEVEDO, A.R.M., VICENTE, J.J. \& VRCIBRADIC, D. 2006. Body size, diet and endoparasites of the microhylid frog Chiasmocleis capixaba in an Atlantic Forest area of southern Bahia state, Brazil. Braz. J. Biol. 66:167-173.

VITT, L.J. \& CALDWELL, J.L. 2013. Herpetology: an introductory biology of amphibians and reptiles. Fourth edition. San Diego: Academic Press. 776p.

WILLIAMS, Y.M., WILLIAMS, S.E., ALFORD, R.A., WAYCOTT, M. \& JOHNSON, C.N. 2006. Niche breath and geographical range: ecological compensation for geographical rarity in rainforest frogs. Biology Letters 2:532-535.

ZAR, J.H. 1999. Biostatistical Analysis. New Jersey: Prentice Hall. 929p.

Received: 17/01/2017

Revised: 19/06/2017

Accepted: 10/07/2017

Published online: 21/08/2017 